\title{
Correction to: NoRCE: non-coding RNA sets cis enrichment tool
}

\author{
Gulden Olgun ${ }^{1,3}$, Afshan Nabi $^{2}$ and Oznur Tastan ${ }^{2 *}$
}

The original article can be found online at https://doi.org/10.1186/ s12859-021-04112-9.

${ }^{*}$ Correspondence: otastan@sabanciuniv.edu

${ }^{1}$ Department of Computer Engineering, Bilkent University, Ankara, Turkey

2 Present Address: Faculty of Engineering and Natural Sciences, Sabanci University, 34956 Istanbul, Turkey

3 Present Address: Cancer Data Science Lab, National Cancer Institute, National Institute

of Health, Bethesda, MD, USA

\section{Correction to: BMC Bioinformatics (2021) 22:294}

https://doi.org/10.1186/s12859-021-04112-9

Following the publication of the original article [1], the authors identifed that Oznur Tastan was incorrectly assigned to affiliation 3 . This has been corrected.

Correct affiliation:

Faculty of Engineering and Natural Sciences, Sabanci University, 34956, Istanbul, Turkey.

The original article [1] has been corrected.

Published online: 04 August 2021

Reference

1. Olgun G, et al. NoRCE: non-coding RNA sets cis enrichment tool. BMC Bioinformatics. 2021;22:294. https://doi.org/ 10.1186/s12859-021-04112-9.

\section{Publisher's Note}

Springer Nature remains neutral with regard to jurisdictional claims in published maps and institutional affiliations.

(c) The Author(s) 2021. Open Access This article is licensed under a Creative Commons Attribution 4.0 International License, which permits use, sharing, adaptation, distribution and reproduction in any medium or format, as long as you give appropriate credit to the original author(s) and the source, provide a link to the Creative Commons licence, and indicate if changes were made. The images or other third party material in this article are included in the article's Creative Commons licence, unless indicated otherwise in a credit line to the material. If material is not included in the article's Creative Commons licence and your intended use is not permitted by statutory regulation or exceeds the permitted use, you will need to obtain permission directly from the copyright holder. To view a copy of this licence, visit http:// creativecommons.org/licenses/by/4.0/. The Creative Commons Public Domain Dedication waiver (http://creativecommons.org/publi cdomain/zero/1.0/) applies to the data made available in this article, unless otherwise stated in a credit line to the data. 